\title{
SOCIAL CAPITAL PRESENCE IN AGRICULTURAL PRODUCT COMMERCE MECHANISM IN SOUTH SULAWESI PROVINCE
}

Eliza Meiyani,

Corresponding Author, emeiyani@yahoo.com

\begin{abstract}
Agricultural commerce in South Sulawesi Province, especially the products, is mostly operated in form of informal relation between commerce practitioners. Due to imperfect condition in the market, social capital thrives and becomes bread and butter in operating entire market system. This article belongs to social system analysis on agricultural product commerce in South Sulawesi as an effort to comprehend the condition constituting background of the operating market system. Writing contents are fetched from previous studies on commerce of various agricultural product commodities as well trader behavior.
\end{abstract}

\section{Indexing terms/Keywords}

social capital, agriculture product, commerce mechanism, south Sulawesi

\section{Academic Discipline And Sub-Disciplines}

Sociology

\section{SUBJECT CLASSIFICATION}

Social Capital

TYPE (METHOD/APPROACH)

\section{Council for Innovative Research}

Peer Review Research Publishing System

Journal: Journal of Social Sciences Research

Vol .7, No.1

jssreditor.cir@gmail.com

www.jssronline.com 


\section{Introduction}

Compared to agricultural activity, commerce activity is a place where humans are making interaction intensively and broadly. Public participation in world market system has gone on for years, and it turns to be more crowded during the Dutch colonialism. For example, some data record export of coffee from Indonesia reaches $7 \%$ of world coffee export, natural rubber reaches 38\%, coconut oil reaches 39\% and lead reaches 18\% in 1937.

Studies all this time concern on agricultural products commerce and mostly, they focus on "goods bought and sold in business", but the trader. Study on agricultural commerce which is observed based on economics point of view usually uncovers marketing chain structure and formation, price and its fluctuation, cost and profit margin, market integration, market efficiency, marketing effectiveness, cost transmission, and so forth. Men operating the activities get rare attention as the special object of the study; those men are trader, transportation company, driver and harbor porter, porter in market, manual worker, weighman, stall owner or others.

As it exists in general social relations which always involve social capital, commerce

Eliza Meiyani, College ofScienceCommunication, Tamalatea. Indonesia, Corresponding Author, emeiyani@yahoo.com practitioner also exist. Schiff, Maurice. (2000) states that in this modern era when free trade and free migration take place, both freedom need social capital. Agree with (Schiff, Maurice. 2000;Brata, Aloysius G. 2004) states that recently, social capital becomes interesting topic discussed and analyzed by people. World Bank states that social capital has significant effect on development process (World Bank. 2000). Development process can be achieved easily with low budget if social capital is available in great quantity (Narayan, D. and Pritchett, L. 1997;Grootaert, C and T van Bastelaer 2001).

According to (Tonkiss, F. 2000), social capital will have economic value if it can assist individual and group, for example to access financial resources, to discover information, to find a job, to open up business, and to minimize transaction cost. In fact, social network, as a part of social capital, will not be enough because it is incapable of creating required physical capital and financial capital. This article aims to comprehend trader closely along with factors affecting their behavior in trading, especially in point of view about form, level, and problem of social capital they own. Social capital shall be understood well since social capital is capable of diminishing imperfection of market institution that is commonly found in agricultural product commerce in South Sulawesi.

\section{Structure of Commerce Practitioner}

Practitioner in commerce involves not only "trader" in term of people who sell and spend money for goods and resell them in some other changes to gain profit. Other than trader, system of commerce also involves worker who assist the trader, transportation company, service provider for weighing, loading and discharging, etc. In one commerce network, commonly, there are many traders involved therein, including collector in village and sub-district level, collector in broader zone level or interregional trader, interisland wholesaler even exporter. In market area, goods will pass from one owner to the other more than once. The goods can be exchanged from interregional merchant to wholesaler, and have an end in retailer.

In analyzing relationship of structure of commerce, it usually starts from "trader" who becomes wholesaler or commerce practitioner in interregional, interisland level, even exporter. Merchants who supply the goods to "trader" is called supplier; this category can be commissioner, broker, or agent(Syahyuti . 1998).Traders receiving the goods from the "trader" operating in market area are called client, retailer and distributor; example of this category is hawker who has kiosk in central market.

Difference between trader and agent is that trader encloses his own capital in transaction, while agent employs capital of other person, i.e. capital from the next trader (closer to consumer) in the market chain. It is not only that commissioner never encloses his own capital or set price of the goods, but also the fact that he does not spend any money to purchase. Common trader has more significant role in market chain, even the number of this intermediaries in one market chain system is small. This type of trader has authority on purchase and market price determination. Different from the other types of trader, this trader type has opportunity to suffer direct financial loss.

\section{Economic Value of Social Capital}

The word of "social" in "social capital" phrase means human relationship, and it does not imply non-economic meaning as attached to "social organization" or "social aid". In the other word, social capital means the capital used in economic activity just the same as financial capital and natural resources. The study conducted by Brata, Aloysius G. (2004) in Yogyakarta found that social capital in form of network across home town has opened social network that exists and functions to acquire informal financial aid and loan when formal aid from the government is so limited. The social capital they own has created economic value for them. This condition is relevant with the findings of Bastelaers (2000) that the poorest member of society who does not have access to microcredit facility utilizes social networks as an important element to fulfill his financing. Social capital is also capable of creating partnership, as one of idealized relations in economic activity. The study of Kolopaking, Lala M. (2002) found that social capital has role starting from initial stage of activity in community level, small business production from community to village organization until collaborative management and collaborative network maintenance. It is true that this process can be success due to the presence of outside party as facilitator, but the social capital existing amongst people has significant role to shape opinion similarities between stakeholders.

Network becomes the means to form sinergy between society and the government. In principles of equivalence, informality and participatory in commitment establishment, problems relating to management in community-based business partnership can be handled in synergically. Therefore, main pillar to make small business partnership 
development and economic region work synergically is by setting up community-based social business. The implication is that management in collaborative partnership development needs moral solidarity of all parties constituting indicator of the social capital arising amongst people.

In modern economic system, enterprises operating stock exchange for example, (Sulastri. 2005) found that intellectual capital possessed by manufacturer which has gone public in Jakarta Stock Exchange (Bursa Efek Jakarta or BEJ) does not contribute significantly to company's performance. Conversely, it is social capital which affects positively company's performance. Sulastri also found that environmental condition, especially economic environment, also takes part in determining social capital effect on company's performance. Company's lifetime also affects positively and significantly social capital formation. Over time, company can improve and maintain the network with stakeholder for mutual trust. Therefore, company shall make an effort to strengthen social capital capacity in internal and external levels in purpose to protect the company from economic environment.

A study in China reports that family spirit becomes the basis of social capital formation that establishes trust in society. To face fast changes in industrial economy, role of practitioner in institution is important matter for the existing social capital sustainability. The study of Fafchamps, Marcel. (2007) in Africa proves that to face agricultural market policy reform, where transactional cost may increase due to individual trader, role of intermediary trader becomes more important, including the network and social capital. Study of Fafchamps also found that the asset possessed by a trader including financial asset, physical asset, human resource and social capital, affects commercialism of the traders.

Study of Fafchamps, Marcel. (2007) with 1579 respondents from trader which is analyzed by economic modeling proves that social capital affects two forms of economic exchange, i.e. trust and emotion arising in the group or network. Profit made in this relationship is gained directly by individual or company by making the acquaintance of other party through the network or customer. Social capital can reduce the cost for goods, improve diffusion of innovation, and reduce the risk. This condition affirms other findings of Fafchamps, Marcel. (2007) that cash advance from trader to farmer, 1-2 weeks before harvest time, is not simply aid only for farmer who needs cash, but it will guarantee the goods farmer have. In his study, social capital is measured based on the number and kind of relations employed by agricultural product trader for his business aims.

\section{Social Capital in Economic System}

In principle, commerce refers to every activity or a number of activities to sell or purchase goods, including offering to sell goods to gain financial return. Asset and business behavior are also affected by presence of formal market institution like business regulatory law and regulation, investigative service, association of commerce and information system. Collective asset along with transport infrastructure, communication and warehousing service directly create trader behavior in business. According to the report published by World Bank (2006), there is concrete evidence that commerce at macro level is affected by social capital. Regardless of the fact that social capital generally exists in microeconomic activity, it has implications on commerce, migration, economic reform and regional integration. Therefore, social capital can be used as identification to assess economic performance(Knack and Keefer, 1997). At macro level, the indicator is trust, while social capital becomes the foundation of economic development (Rafael La Porta, et al, 2000).

Social capital exists in both economic system, modern and traditional. Traditional economic system, in general, has "market" characteristic marked by traditional market transaction. Traditional market has to be explored broader; first, as a place where we can purchase goods and services, and second, as a place where collective agreement is made to operate economy. This kind of market is a part of socio-culture which has firmly rooted in society. In Indonesia, socio-economic culture has been established for years in form of 'traditional market economic' system which does not change a lot (Ramelan, Rahardi. 2002).During the economic crisis we face in the end 20th century, traditional market economy keep standing firm. This is evidence that during the crisis, society was capable of looking for social capital strength root from traditional market economy. Traditional market can hold out because of the social capital existing amongst practitioner.

In economic globalization we live within and face, traditional market economy still becomes mainstay of our economic system. The traditional market system-based economic resistance shall be integrated with modern economy. Special social capital living within society shall be transformed to make it new strength for modern economy. Some principal traits of traditional economy are informality, small business size and women's participation. Women are business actress in traditional or informal sector. According to (http://www.leapidea.com/presentation) women's participation in commerce, especially small scale business, is caused by narrowing farmland in rural area that set women aside from agricultural activity dominated by men. Considering irregular agricultural activity year around, women work in non-agriculture to add household finances, become a trader in market for example. In this context, women who were object of economic are changing into be active subject of economy. It is a sort of women's existence reformulation since women's existence is always pushed aside in social system. However, trade sector constitutes power domain that give women spaces to perform social mobilization. At least, they have a chance to leave zone dominated by men, i.e. house and agriculture.

According toBrata, Aloysius G. (2004), social capital gives economic benefits to actor in urban informal economic activity. Regarding informal social network, social capital also determines the process of being trader, including the place where trading will be held. Experience of being trader is an important factor on why someone makes decision to start up business, including causes of resignation from previous job. (Payne, Malcom. 1997) states that in daily life, social capital refers to one of resources or capital used by individual as a strategy to solve daily life problems. When the job does not give them sufficient income, people are looking for part time job which is generally determined by social capital they own, i.e. membership in individual social network. The study of Fafchamps, et al. (1999) has conclusion that accumulation of social capital is proven having concrete role in business. Assessment of social capital represents significant raising added 
value over means ownership, labor capital, human capital and management skill. Two important factors in developing social capital are on number of trader known by individual and number of people who are ready to help when problem raises. Besides, non-family relationship is proven to have contribution compared to family ties.

\section{Social Capital in Agricultural Product Commerce System}

Agricultural product commerce is generally found in imperfect market. Imperfection is indicated by structural and cultural weakness of market institution, inefficient and huge transaction cost, and incomplete and imbalance information structure. Facing up current condition, social capital is more important. Key success factors in trading, according to traders, are reputation and relations. Both factors are more important than access to capital, ownership of credit guarantee, position in commerce structure and access to transportation and communication. Reputation and relations are two main components in social capital. Reputation is built on trust granted by other party to us, while relation is an institution where interaction takes place. Adequate relation in quantity and quality can give double benefits. Fafchamps, Marcel. (2007) found that trader makes the use of network and social capital to handle three important problems faced in imperfect market; this condition is commonly found in developing countries.

Weak market institution can be seen in three factors: capital, trade contract and insurance. It is broadly known that credit use among traders is too low that help their activity a little. Different from farmers who have many credit schemes provided by the government, trader does not have these options. Trader can access general credit scheme though, but minimum loan security still becomes their obstacle. In this condition, social capital can help trader to access informal credit. (Busse, S. 2001). agrees that causal factors of underdeveloped traditional market are minimum support capacity for traditional traders in term of lack of planning strategy, and limited capital access due to insufficient collateral value.

Trader usually gets capital from other trader when at the same time, it means trader's self acceptance in the commerce system. Complex and branching credit balance network is one of mechanisms that ties all types of traders, wholesaler and small trader together, and it also becomes integrative factor in the market (Geertz, Clifford. 1989). Wholesaler lends credit to small trader, or in other word, small trader owes wholesaler. This kind of debt does not aim to get the capital only, even this loan constitutes a mechanism to reach a position in the commerce network system. (Putnam, R. 1993) also found that cooperation with buyer can be gained by pricing and joint capital. And so (Damanik, Kontalntan. et al.. 1983) who found that financial aid between traders is main capital source for trader. Concerning on trade contract, just the same as credit, trader rarely uses the power of contract. When traders encounter problems, only a few of them call the police, attorney or court for help. Dominant problem solving when problem arises is by asking mediator to arrange negotiation. However, as stated by Fafchamps, et al. (1999), common way out to solve the problem is by letting commerce goes on. End of dispute is handled by negotiation since, in principle, all traders expect relationship continuity. Relationship they had built is more valuable than the accrued charges, for example. A trader will find it hard to have new supplier if he loses one of his regular suppliers.

Concerning on cash collateral in business, agricultural commodity is known for its varied quality and risks. The greater risks are caused by various factors: bad road conditions, safety risks, weather effect, high price fluctuation and unidentified risks, for example late payment, or even with no payment, and undetectable poor quality. Due to the absence of formal institution that is capable of providing collateral for agricultural commerce, social capital has an important role for this reason. Consequently, all traders are consolidated in one informal insurance mechanism, where wholesaler prefers holding his solidarity network to his rival small trader. A wholesaler believes that he will get some help from his family or other people in need, and so does his readiness to help people. Small trader otherwise believes his personal capacity with no assistance from outside party Fafchamps, et al. (1999).

Social capacity obviously takes its role in any condition faced by market institution, weakness or failure. The roles of social capital are: 1) credit resource, when formal credit is not accessible, 2) insurance by joint risks at which the goods are not paid before they are sold, while pricing is set later on, 3) substitution when the power of contract from formal institution does not run well, or uneconomical. Furthermore, high cost in commerce is caused by supply, demands and commerce service. High cost of supply is caused by limited supplier selection. To guarantee goods supply, a trader shall grant incentive to supplier that allow him to regularly supply the goods. Therefore, sometimes the trader pays cash the goods, or pays in advance. For a greater-scale trader, this dependence is more visible. Thus, it is known that relations established between traders and regular supplier in a long time is common pattern. This relation, in general, has stronger ties than family, religion or ethnic ties.

When a trader has close relation with supplier, he can make ordering of goods. Strong relationship with the supplier can prevent trader from loss due to poor goods quality. Trader is unable to search through the goods quality fast. Therefore, trader will refuse to take goods from supplier he does not know well. Subscription pattern is the most suitable strategy to cope various weakness of market institution. Presumably, there is no 'completely open' transaction pattern at which there is no certainty in price and person who has this business agreement. Almost all traders are bond in a somewhat steady organizational structure. The trader purchasing goods can be ascertained who the person is since he is tied to the subscription. This subscription pattern is two-way relationship starting in stages from branch trader and collector trader in village to the next and final transaction between wholesaler and retailer. If it is traced from farmer to consumer, it is only a transaction between retailer and end user (consumer) which is completely open since everyone is able and has an opportunity to be the subject of transaction (consumer).

Regarding the demands, to reduce the cost, most of traders sell goods to end trader they are familiar with or regular end trader. This strategy is executed that will allow trader to get refund if the goods are unqualified. A trader will choose client as client's capability and morality in reducing marketing cost. Concerning on commerce service, to reduce the cost, most 
traders utilize same transportation service. And, this decision is better. This attitude is same as attitude treated to supplier or client since subscription relationship has had strong mutual trust. Dealing with perishable agricultural commodity and insufficient warehouse, the establishment of regular relationships upstream and downstream might be in the interest of traders, clients and suppliers alike. Infrastructure still becomes serious problem in traditional market. Worrisome condition is usually found in traditional market because most markets are not well maintained (Busse, S. 2001).. Based on various strengths offered by modern market, existence of traditional market is in danger.

Dealing with imperfect and imbalance information structure, social capital development is also capable of producing understanding among important practitioners. Concerning on weak market institution, trader are making an effort to be more efficient through supplier-client network establishment. Purposely, it can open a satisfactory path in commerce, for example by lending and receiving loan, making order and reducing necessities to check into the goods quality.

Trader can acquire market information from personal relationship and other trader, supplier, client or mass media like newspaper and radio. To achieve the more satisfactory trading system, trader shall build stable system in term of mutual trust with clients and suppliers for the better contract. In this context, trader always evaluates credibility degree of his customers. Credibility can be reached by longterm relationship development where a trader seldom lend or receives loan to supplier or his downstream trader he has just known latelyFafchamps, et al. (1999) found that a trader has the courage to lend a loan if transaction has been held five to ten times. If trust has not established, trader tends to arrange direct transaction. Dealing with lack of information on the trade goods, trader usually checks the quantity and quality of sort samples. Quality of goods generally depends on the place where they come from. Trader checks the quality, and appraises its price based on his assessment. Sometimes, goods checking is done by worker, but in particular condition, the trader does it.

Trader is closed for outsider, and he is inclined to be suspicious. (Sihite, Romany Rampengan. 1995 ;Wharton, Clifton R. 1984; Hayami, Yujiro dan Toshihiko Kawagoe. 1993). report that during their research, they are less successful to approach trader respondents, while answers they utter are less valid. Closed-minded personality emerges due to traders' habit to keep information they have. For traders, information is the most valuable resources. To find out the more satisfactory goods quality, trader shall take direct observation in the location where goods are produced. It implies the importance of social capital where the trader is no need to check the goods if he has put a great trust to his colleague. Implicitly, it reduces commerce cost, or even eliminates the cost. Growth rate of commerce carried out by trader will be finite if he cannot use and build up social capital. (Sihite, Romany Rampengan. 1995 ; [24] concludes that the stronger trader, the broader marketing network he has, thus his market is growing.

\section{Conclusion}

The details prove that social capital is growing, and it is accumulated for years that significantly affects performance of agricultural commodities commerce system. Social capital can reduce the effect of market imperfection faced by commerce practitioner. Social capital reduces the height of transaction cost through three dimensions: 1) relationship with other trader can reduce transaction cost, 2) relationship with people will be beneficial if the trader encounters financial difficulties because business world means living in great risk, 3) relationship with family will make things efficient and reduce mistakes in examining quality of the goods. Making social capital grow can be conducted formally by creating association of traders to cut down the impact of business, ethnic-based association for example, and facilitating well built communication and information. Establishing legal system and court to serve commerce may be disadvantageous when small traders seldom utilize this institution due to its uneconomical nature.

In order to develop social capital, the keyword is "time". Social capital possessed by trader is increasing along with trader's involvement in commerce. It needs sensitivity that will keep growing over times, and effort to make relationship with someone who will be ready in need when problem arises, especially financial difficulties. Implication of this conclusion is that to improve marketing, policy can intervene these four important effort: increasing trader's asset, reducing transaction risks, promoting the better business behavior and reducing commerce cost.

\section{References}

[1] Bastelaers (2000). The World Bank Social Development Department Social Capital Working Paper Series Attention Ms. Gracie M. Ochieng 1818 H Street, NW, Room MC 5 - 410 Washington, DC 20433, USA

[2] Brata, Aloysius G. 2004. EconomicValueof SocialCapitalinthe UrbanInformal Sector.Research Institute ofthe University ofAtmaJaya.

[3] Busse, S. 2001. Strategis of Daily Life: Social Capital and the Informal Economy in Russia." University of Chicago De partement of Sociology (Sociologial Imagination 38 (2/3) Special Issue on the Informal Economy).

[4] Coleman, J. 1988. "Social Capital in the Creation of Human Capital." American Journalof Sociology 94. (Supplement) S95 - S120. (In: The World Bank. 1998. Hal 5 - 7).

[5] Damanik, Kontalntan. et al.. 1983. The role ofbrokerin theProductionandMarketingSystemsGoat/SheepinCentral Java. (hal. 220 - 225) in M. Rangkuti, Tjeppy D. Soedjana, H.C. Knipscheer, P. Sitorus, andAgusSetiadi (editor).

SheepandGoatsinIndonesia.Proceedings ofSmallRuminantResearchScientific Meeting.Bogor.22 to 23 November1983.

TheCentre for ResearchandDevelopmentof Animal Husbandry(315 pages). 


\section{ISSN 2321-1091}

[6] Fafchamps, Marcel. Global Poverty Research Group. 2007. Trade and social capital. http://www.gprg.org/themes/t4 soccap - pub - so csafe/sc - uses/trade - sc.htm .20 agustus 2007.

[7] Fafchamps, Marcel dan Bart Minten. 1999. Social Capital and the Firm: Evidence from Agricultural Trade. http://www.appropriate - economics.org/materials/social_capital_an d_the_firm.pdf .4 Desember 2007.

[8] Grootaert, C dan T van Bastelaer. 2001. Understanding and Measuring Social Capital: A Synthesis of Findings and Recommendations from the Social Capital Initiative. Social Capital Initiative Working Paper No. 24. Washington, D.C: The World Bank.

[9] Grootaert, C. 1997. "Social Capital: The Missing Link?" in E xpanding the Measure of Wealth: Indicators of Environmentally Sustainable Development .Environmentally Sustainable Development Studies and Monographs Series No. 7. Washington, DC: The World Bank. (Dalam The World Bank. 1998. Hal 5 - 7).

[10] Geertz, Clifford. 1989.Social ChangeandEconomicModernizationinTwo CitiesIndonesia. YayasanObor Indonesia. Jakarta. (172 hal).

[11] Hayami, Yujirodan Toshihiko Kawagoe. 1993. The Agrarian Origins of Commerce and Industry: A Study of Peasant Marketing In Indonesia. St. Martin's Press. Singapore.

http://www.leapidea.com/presentation\%3Fid\%3D41+social+capital+modal+sosial+di+perdagangan \&hl=id\&ct=clnk\&cd=1\&gl=id , 10 November 2014.

[12] Kolopaking, Lala M. 2002. PartnershipPatternsinSmallScaleEnterprise DevelopmentEconomics.National Workshop on"Regional Economic DevelopmentThroughSynergyDevelopment of Regions". organizedbyDirectorate ofSpecial AreasandDisadvantagedMinistry ofNational Development Planning/Bappenas. 4 - 5 November 2002 Jakarta.

[13] Knack and Keefer, 1997. Does Social Capital Have An Economic Payoffa Cross-ountry Investigation, The Quarterly Journal Of Economics, November 1997

[14] Narayan, D. dan Pritchett, L. 1997. Cents and Socialibility: Household Income and Social Capital in Rural Tanzania, Policy Research Department, the World Bank, Washington DC, August 1996. (Mimeograph) Poesoro, Adri. 2007.

Traditionalmarketsinthe Era ofGlobal Competition. SMeruNewsletterNo.22: April to June/2007. InstituteResearch Institute. Jakarta.

[15] Putnam, R. 1993. "The Prosperous Community-Social Capital and Public Life."American Prospect (13): 35 - 42. (DalamThe World Bank. 1998. Hal 5 - 7).

[16] Rafael La Porta, Florencio Lopez-de-Silanes,AndreiShleifer, obertVishny (2000). Investor Protection And Corporate Governance. Journal of Financial Economics 58, 3.

[17] Ramelan, Rahardi. 2002. Dealing withForeign Capital: Part OneofTwoPosts.

Payne, Malcom. 1997. Modern Social Work Theory. Second Edition. MacMillan Press Ltd., London. Hal. 266.

[18] Robin, Lionel. 2005. Institutional Economics. http://www.msu.edu/user/schmid/bromley.htm, 19 November 2014

[19] Sihite, Romany Rampengan. 1995. ActivityPatternWomenin the Informal Sector; Especiallyinthe

MarketVegetableMerchants. (hal 375 - 400) In T.O. Ihromi (penyunting). 1995. Study ofWomenin Development.

TorchFoundationIndonesia.Jakarta. (549 p.).

[20] Schiff, Maurice. 2000. Love Thy Neighbor: Trade, Migration and Social Capital World Bank - Development Research Group (DECRG); Institute for the Study of Labor (IZA). May 8, 2000. World [21] Bank Working Paper. http://papers.ssrn.com/sol3/papers.cfm?ab stract_id=229615 . 6 Desember 2007.

[21] Sulastri. 2005. Effect ofIntellectual CapitalandSocialCapitalonEmployeeCompensationandCorporate Performance. Prasetya.brawijaya.ac.id/mar05.html-210K. 10 November 2007.

[22] Syahyuti . 1998. SomeCharacteristicsandBehaviorMarketingMerchantsKomo-ditasResults-Agricultural ProductsinIndonesia. Forum Agro Ekonomi Vol. 16 No.1, Juli 1998.

[23] Tonkiss, F. 2000. Trust, Social Capital and Economy.Dalam F. Tonkissdan A. Pasey (eds.). Trust and Civil Society New York: St. Martin's.

[24] Wharton, Clifton R. 1984. Marketing, TradeandLoanMoney: Study ofmonopsonyBrokerDealerin West Malaysia (hal143 - 169). dalamBudionodan Peter McCawley (editor). BungaRampaiEkonomiMikro. Gajah Mada University Press.YayasanObor Indonesia.(228 p).

[25] World Bank. 2000. World Development Report 1999/2000: Entering the 21st Century .New York: Oxford University Press. http://www. acehinstitute.org/o pini_muamar_vebry_071206_dead_capital.htm .10 Mei 2005.

[26] World Bank, 2006. Social Capital in Economics, Trade and Migration http://www1. worldbank.org/ prem/poverty/scapital /topic/ econ1.htm . 10 Mei 2005 